\title{
Authority, Philology and Conversion under the Aegis of Martín García ${ }^{1}$
}

\author{
Teresa Soto and Katarzyna K. Starczewska
}

The Cédula Real (Royal Charter) signed by the Catholic Monarchs on 24 October 1500 requested secular clergy to go to Granada to participate in the preaching campaigns addressed to the newly converted population. ${ }^{2}$ These clergymen came mainly from Castile but also from other places in Spain, as was the case of the future bishop of Barcelona, Don Martín García Puyazuelo (ca. 1441-1521), from Aragon. García, archdeacon of Daroca at the time, had some knowledge of Arabic, and enlisted the help of various other clergymen with varying degrees of familiarity with the language. All of the latter were from Valencia, where, as in Granada, Islam and the Arabic language continued to have a strong presence. Lope de Obregón, Juan Andrés, Joan Martín de Figuerola and Bernardo Pérez de Chinchón participated in this group involved in preaching activities first in Granada and later in Aragon, and also produced books to promote Christianity and to combat Islam. ${ }^{3}$ A representative sample of this literature is the books we are going to consider here, written by Juan Andrés (Confusión o confutación de la secta mahomética y del alcorán, 1515);4 and Joan Martín de Figuerola (Lumbre de fe contra la secta mahometana y el alcorán, 1521). ${ }^{5}$ Among the production of preaching material from sixteenth-

1 The research leading to these results has received funding from the European Research Council under the European Union's Seventh Framework Programme (FP7/2007-2013) ERC Grant Agreement number 323316, project CORPI: 'Conversion, Overlapping Religiosities, Polemics, Interaction. Early Modern Iberia and Beyond'.

2 Darío Cabanelas Rodríguez, 'Los moriscos. Vida religiosa y evangelización', in La incorporación de Granada a la Corona de Castilla. Actas del Symposium conmemorativo del quinto centenario, (ed.) Miguel Ángel Ladero Quesada (Granada: Diputación Provincial, 1993), pp. 497-513.

3 Mercedes García-Arenal and Katarzyna K. Starczewska, 'The Law of Abraham the Catholic': Juan Gabriel as Qurānn Translator for Martín de Figuerola and Egidio da Viterbo', Al-Qanțara, 35 (2014): pp. 409-59, esp. p. 415 .

4 Juan Andrés, Confusión o confutación de la secta Mahomética y del Alcorán [Valencia, 1515], (ed.) Elisa Ruiz García and María Isabel García-Monge (Mérida: Editora Regional de Extremadura, 2003).

5 Joan Martín de Figuerola, Lumbre de fe contra la secta mahometana y el alcorán, 1521. Madrid, Biblioteca de la Real Academia de la Historia [RAH], ms. Gayangos 1922/36. Partially edited by

(C) TERESA SOTO AND KATARZYNA K. STARCZEWSKA, 2016 | DOI 10.1163/9789004324329_009

This is an open access chapter distributed under the terms of the CC-BY-NC-ND License. 
century Spain, they were the earliest works within this modern polemical production, and were to have a germinal role in the trends of the polemical and preaching literature to come. ${ }^{6}$ We would like then to start by introducing the figure of García and his connection to both authors with whom this study is concerned, Juan Andrés y Joan Martín de Figuerola. We believe that his approach to Arabic and Islam was unique among the other trends of the period, and it is clear that around him a distinct circle of authors arose with common ideological underpinnings.

The way Juan Andrés and Figuerola presented their arguments differed, as did their background, but we find that the lines that connect them to one another are compelling enough to merit a comparative study elucidating points where their rhetoric both converges and differs. At the textual and ideological level, they made the fascinating decision to include actual quotations in Arabic from the Qurān. Thus, the formal inclusion of this highly 'dangerous' material in their texts will be at the heart of this chapter, where we will examine the context in which such a decision arose, what goals the authors pursued in using (appropriating?) qurānic material, and what intellectual risks they exposed themselves to. It is our view that such a use of the Arabic language and Islamic sources as tools to legitimate this anti-Islamic enterprise created a proximity that proved far from comfortable, in fact producing a tension that would manifest itself in an unexpected dependency on the opponent. We will then examine how Figuerola incorporates qurānic quotations into his work Lumbre de fe. Along the way we will also point out the different argumentative tactics employed by Figuerola and Juan Andrés, and conclude by providing some insight into how Juan Andrés constructs his own authority.

Other than studying the use of a textual authority, represented here in the qurannic quotations (and how this text is formally represented), we would also like to consider another aspect that recurs in both Lumbre defe and Confusión, which is how the leading figures of the Muslim communities - the so-called alfaquís, literally scholars of the law, jurists - are represented. ${ }^{7}$ It is striking how dominant the figure of the alfaqui is in both texts, which has made us wonder what connection they have with the use of textual authority, and how

F. Guillén Robles in Leyendas de José hijo de Jacoby de Alejandro Magno sacadas de dos manuscritos moriscos de la Biblioteca Nacional de Madrid (Zaragoza: Imprenta del Hospital Provincial, 1888). See Elisa Ruiz García, 'Joan Martí Figuerola', in Christian-Muslim Relations: A Bibliographical History. Vol. 6: Western Europe (1500-160o), (Ed.) David Thomas et al. (Leiden: Brill, 2014), pp. 89-92. Elisa Ruiz García and Luis Bernabé Pons are currently preparing an edition.

6 See in this volume Chapter 6 by Ryan Szpiech.

7 See infra note 71 . 
they become such an important rhetorical element in the discourse of both Juan Andrés and Figuerola. Juan Andrés, a converted alfaquí himself, and Figuerola (who worked hand in hand with Juan Gabriel, also a converted alfaqui), used and represented this figure in ways that are worth considering. While on the one hand there is a clear interest in addressing the leader in order to convert him and bring with him the whole community, there is at the same time a manifest effort to diminish this very same authority so as to accuse the Muslim communities themselves of ignorance. The alfaquís-turned-Christian collaborators Juan Gabriel and Juan Andrés are not just mediators but also authorities, not just informants but also figures of speech.

\section{'Que vos sabeys arabigo': Preaching under the Aegis of Martín García}

It is not very clear what role Juan Andrés and Joan Martín Figuerola had in the sixteenth-century Spanish church. We know that by 1516, a year after the publication of his Confusión, Juan Andrés was a canónigo in Granada, and that he had translated the 'Koran and the books of the Sunna' by the request of the bishop of Barcelona, Don Martín García (ca. 1441-1521). ${ }^{8}$ We also know that Joan Martín Figuerola, ${ }^{9}$ a beneficiado en la iglesia mayor de Valencia, undertook the assignment at the See of Zaragoza to preach four sermons a year to the Muslims, as instituted by the Catholic Monarchs and at the request of the same García, who was then too old to carry out the task himself. ${ }^{10}$ After Aragon, Figuerola moved back to his native city of Valencia and wrote Lumbre de fe, which he completed on 19 June 1521. Thus, the name of Martín García recurs in the books produced by both authors, and in both he appears as a key figure

8 Juan Andrés, Confusión, p. 91. Gerard A. Wiegers identifies Juan Andrés as the canon in his article 'Moriscos and Arabic Studies in Europe,' Al-Qanțara, 31 (2010): pp. 587-610, esp. p. 589. See also Rafael Marín López, El Cabildo de la Catedral de Granada en el siglo XVI (Granada: Universidad de Granada, 1998), p. 438.

In his 'Prólogo' he presents himself as: 'Mossen Johan Martín de Figuerola, maestre en sacra teología, acólito y capellán de su santidad, simple beneficiado en la iglesia mayor de la insigne ciudad de Valencia. Principiado el día de todos los santos de 1519...dirigida a Su Majestad el rey'. Madrid, Biblioteca de la Real Academia de la Historia, RAH, Gayangos 1922/36 (quoted here as Lumbre de fe), fol. 253 .

'El presente autor predicando en la yglessia mayor de Saragoza en presencia de los moros que eran unos sermones de la fe los quales el rey Católico Fernando de Aragón le mandó que tomara el cargo por la antigüedad del Mq Xd Martín García, obispo de Barcelona'; Martín de Figuerola, Lumbre de fe, fol. 103r. 
who commissions and leads, and it is not difficult to imagine that he had a preeminent role in the formative period of both priests as well as in the orientation of their ecclesiastic careers.

The trajectory of Martín García was remarkable: in 1487 he preached before the Catholic Monarchs in Zaragoza and was chosen as Fernando II's preacher and Isabel I's confessor, in addition to being made archdeacon of Daroca and Inquisitor of Aragon in 1484. ${ }^{11}$ Later on, in 1493, he was given the title of Reformador de religiosas, a title which was ratified in 1495 , before being finally appointed as the bishop of Barcelona in 1515, six years before his death in 1521 . As a churchman distinguished by the Catholic Monarchs, García participated in the evangelization of the Muslims of Aragon, whose conversion did not become mandatory until 1526 .

He already had an instrumental role in the evangelization of the population of recently conquered Granada when in 1500 the Catholic Monarchs wrote the aforementioned letter to García, then archdeacon of Daroca, asking him to go and preach to the newly converted Christians from Granada, arguing that his knowledge of Arabic made him the ideal person for this mission: 'to instruct the aforementioned newly converted because we know that you know Arabic and that with your education and preaching and good example they can greatly benefit from you.'12 When and how Martín García learned Arabic is not clear. He spent most of his early years at the See of Zaragoza, where he learned Latin, philosophy and grammar. Most probably due to his proselytizing activities in Aragon, García learned some Arabic, though he could have also

11 Juan Francisco Sánchez López, 'Martín García Puyazuelo y su papel en el establecimiento de la Inquisición en Aragón', Anuario del Centro de la UNED en Calatayud, 13 (2005): pp. 233-44. José María Lahoz Finestres and Eugenio Benedicto Gracia, 'Una relación de Autos de Fe celebrados en Aragón de 1485 a 1487', Revista de la Inquisición (Intolerancia y derechos humanos), 15 (2011): pp. 13-25.

'Maestre Martin Garcia, ya sabeys como todos los moros de la ciudad de Granada se convirtieron a nuestra santa fe catholica; porque muy pocos dellos saben entender hablar sino arabigo y por no haver personas de iglesia que sepan el arabigo, no pueden los dichos convertidos ser bien instruidos en las cosas de nuestra fe y ay mucha necesidad - especialmente agora en los comienzos que no hay en aquella ciudad personas de iglesia que sepan arabigo para instruir a los dichos nuevamente convertidos y porque sabemos que vos sabeys arabigo y que con vuestras letras y predicacion y buen ejemplo podreys muchos aprovecharles, porénde nos vos rogamos y encargamos que pues vedes quanto en ello sera servido nuestro Señor querays disponer os a venir a estar algun tiempo a la dicha ciudad para aprovechar en lo susodicho que mas de lo que con ello mereciereys de nuestro Señor a nos fareys muy agradable servey'; Ribera Florit, 'La polémica cristiano-musulmana en los Sermones del maestro inquisidor don Martín García' (BA thesis, Barcelona 1967), p. xxix. 
learned it at the University of Bologna, where Arabic was taught at the time and where he earned the degree of Master in Theology in $1480 .{ }^{13}$ Little information, however, is found about this very last formative period in Bologna, and nothing at all about his possible knowledge of Arabic. ${ }^{14}$ The documents from the Collegio di Spagna in Bologna indicate only the dates of entry and exit from the Collegio and the University, but little else..$^{15}$

In addition to being called to Granada, García's knowledge of Arabic also led to an appointment by the Catholic Monarchs to preach to the Muslim population of Aragon. There he delivered the so-called Sermones de la Fe until, as mentioned, Joan Martín Figuerola eventually substituted him in this task. Of note in his sermons, however, is the fact that numerous expressions in Arabic are included for the purpose of exhorting the listener and, as in Figuerola and Juan Andrés, a fair amount of qurānic quotations reinforce and support the arguments he constructs in order to prove Islam wrong. ${ }^{16}$

In the Council of Vienna 1311-12 it was decided to establish Chairs of Hebrew, Arabic and Chaldean in the studies and universities of the Roman Curia (Paris, Oxford, Bologna and Salamanca). In Salamanca, the rules set forth at the council were partially implemented by 1381 . See the Prologue by Concepción Vázquez de Benito in Actas XVI Congreso European Union of Arabists and Islamicists, (ed.) C. Vázquez de Benito and Miguel Ángel Manzano Rodríguez (Salamanca: CSIC, AECI, 1995), pp. 7-9.

In the biography of García written in 1700 by José Hebrera y Esmir (1652-1719), a Franciscan and chronicler of Aragon, we can find abundant information about the bishop even though it also constitutes a rather embellished narration which by turns fictionalizes some of the main milestones in García's life with miraculous events linked to the city of Zaragoza. Among them: his humble origins, the fact of being born to a family of old Christians from Caspe, and his astonishing progress from being a pastorcillo (shepherd boy) to becoming a Maestro de Teología por la gravisima Universidad de Bolonia (Master in Theology by the illustrious University of Bologna). Joseph Antonio de Hebrera, Vida prodigiosa del ilustrísimo y venerable D. Martín García, obispo de Barcelona, hijo de la fidelíssima y antigua villa de Caspe (Zaragoza: Domingo Gascón, 1700). Antonio Pérez Martín, Proles Aegidina (Bologna: Publicaciones del Real Colegio de España, 1979), pp. 384-85.

16 Martín García Puyazuelo, Sermones eminentissimi totiusque Barchinonensis gregis tutatoris acerrimi necnon immarcessibilis sacre theologie paludamento insigniti Martini Garsie (Zaragoza: Jorge Coci, [1520]). See Manuel Montoza Coca, 'Edición, traducción y comentario de los sermones I-V de Don Martín García', (MA Final Diss., Barcelona: Universitat Autònoma, 2013). The pattern of inserting Arabic expressions in García's sermons presents itself as follows: 'Igitur, ismaelite, proximi mei, postquam cognoscitis Ihesum, filium uirginis Marie, per sanctissimo propheta, et cum magna reuerentia in scriptis uestris illum notatis dicendo: 'çahidine Yce', quod significat 'Dominus noster, Iesus'; 'aleyiççalem' quod sonat 'gaudetur ipse', et similem matrem suam, uirginem, cum magna reuerentia notatis dicendo: 'çetina Marien', quod sonat 'domina nostra Maria sit benedicta'. Igitur 


\section{Approaching Arabic}

The attitudes of Christian writers and polemists towards the use and knowledge of Arabic were to vary widely through the sixteenth and early seventeenth centuries, but were to tend towards a progressive prohibition of the Arabic language, and to unambiguously associate it with Islam. ${ }^{17}$ At the first stage of indoctrination, however, Arabic as language is still seen as necessary in order to preach, and to thereby attain the full conversion of the target audience, as is made clear in the Catholic Monarchs' aforementioned appeal to Martín García. Except for this letter, there is little information about what role Arabic actually played in García's preaching in Granada. However, based on the written material García, Juan Andrés and Figuerola left behind, the way in which they included isolated qurānic fragments and Arabic expressions seems to indicate that their aim in using Arabic was, for example, quite unlike that of the first archbishop of Granada, the Hieronimyte Hernando de Talavera (ca. 1428-1507), who, at the time of García's arrival in Granada, had been the main figure involved in preaching to the newly conquered population. Nor was their aim comparable to the evangelizing trend dating back to before the foundation of the Society of Jesus (1540), such as the bilingual school in Gandía, the school for girls, and the House of Doctrine, among others, ${ }^{18}$ projects which connected

uos, ismaelite, mediante ista uirgine conuertimini ad Christum, uerum pastorem, et hic inuenietis gratiam et in futuro gloriam quam nobis concedat etcetera. Amen'. Martinus Garsie, Sermones, Sermo xxx in: Manuel Montoza Coca, 'El uso de Bernardo de Claravall como autoridad en los Sermones de Don Martín García' (forthcoming). 'You, Ishmaelites, my neighbors, now that you acknowledge Jesus, son of the Virgin Mary, as the most sacred Prophet and with great reverence you call him in your writing saying "çahidine Yce", which means "Jesus, our Lord", "aleyiççalem", which means "Praise be to him"; and equally you most reverently call his mother the Virgin saying: "çetina Marien" which translates: "Praise be to Maria, our lady", therefore, you, Ishmaelites, through this Virgin convert yourselves to Christ, the true Shepherd; and here you will find grace and in the future glory which will be granted to us. Amen'.

For more on evangelization in Granada in the second half of the sixteenth century, see Mercedes García-Arenal and Fernando Rodríguez Mediano, The Orient in Spain: Converted Muslims, the Forged Lead Books of Granada and the Rise of Orientalism (Leiden: Brill, 2013), pp. 42-56. Also, Rodríguez Mediano, 'Conversion, langue et historie: la christianisation de la langue arabe dans l'Espagne moderne', in Les musulmans dans l'histoire de l'Europe. Vol. II, Passages et contacts en Méditerranée, (ed.) Jocelyne Dakhlia and Wolfang Kaiser (Paris: Albin Michel, 2013), pp. 537-63. dos en la España del siglo XVI (Granada: Diputación Provincial, 1987), pp. 101-19. Francisco de Borja Medina, 'La Compañía de Jesús y la minoría morisca (1545-1614)', Archivum 
in a broad way with the missionary trend initiated by the Hieronimite archbishop. Talavera's approach to conversion implied what could perhaps be called an ideology of substitution, a way of suppressing one already existing religion (Islam) with a new one (Christianity). While the transfer from one faith to the other implied a progressive abandonment not just of religious practice but also of converts' cultural habits and native language, it also involved a search for common ground between both religions. ${ }^{19}$ In fact, with the aim of providing the preachers with a basic knowledge of Granadan vernacular Arabic, Pedro de Alcalá - who was a disciple of Talavera but about whose biography we know very little - composed the Arte para ligeramente saber la lengua aráviga and the Vocabulario arávigo en lengua castellana (1505) following Talavera's instructions and philosophy. ${ }^{20}$ The Arte and the Vocabulario expressed a concept of the vernacular Arabic as a vehicle to offer the new converts Christian doctrine in the language they understood best, and also provided previous concepts that could have been used in the substitution of Islamic doctrine for Christian doctrine. ${ }^{21}$ Alcalá's Arte is also full of interesting remarks about the dialect and the grammatical components of Arabic that reveal his philological interest in the language, despite his initial declaration of not wanting to delve deeper into the problems of the Arabic language, but rather treat them superficially and offer only insights into the language of the people. $^{22}$

In contrast to an approach like Talavera's, which used the Arabic language as a vehicle for purely Christian doctrine (even if it intended to end up suppressing it), what Martín García and his circle are known for is producing doctrinal

Historicum Societatis Iesu, 57 (1988): pp. 4-137. Also, Youssef El Alaoui, 'Ignacio de las Casas, jesuita y morisco', Sharq Al-Andalus, 14-15 (1997-98): pp. 317-39; and by the same author, Jésuites, Morisques et Indiens. Étude comparative des méthodes d'évangélisation de la Compagnie de Jésus d'après les traités de José de Acosta (1588) et d'Ignacio de las Casas (1605-1607) (Paris: Honoré Champion, 2006).

19 'Lo primero, que olvidéis toda ceremonia y toda cosa morisca en oraciones, en ayunos en pascuas y en fiestas y nasçimientos de criaturas y en bodas y en baños, en mortuorios y en todas las otras cosas'. In Antonio Gallego Burín and Alfonso Gámir Sandoval, Los moriscos del reino de Granada según el sínodo de Guadix (1554) (Granada: Universidad de Granada, 1968), p. 161: 'Memorial' (from Hernando de Talavera to the Moriscos of the Albaicín). Pedro de Alcalá, Arte para ligeramente saber la lengua aráviga (Granada: Juan de Varela, 1505).

21 García-Arenal and Rodríguez Mediano, The Orient in Spain, pp. 39-46.

22 'Pero destos y de otros primores yo no curo, porque mi intención principal es hablar y enseñar la lengua de la gente común y no los primores de la gramática aráuiga'. Pedro de Alcalá, Arte, fol. aV. 
works which focused on combating Islam mainly through the use of Islamic sources. These polemical materials in Latin and Romance were fully furnished with qurānic quotations, both in translation and also in the Arabic original. It could perhaps be argued that these treatises were made with the average Muslim of Aragon in mind, who did not use Arabic as a spoken language. Thus, the inclusion of Arabic quotations in the preaching materials would have been less important than, say, in Granada. However, we know that by 1516 Juan Andrés was already a canónigo in Granada, and that Martín de Figuerola, after his lack of success in Aragón, moved back to his native city of Valencia and wrote his book, which he completed on 19 June 1521, although he never published it. Indeed, in both Valencia and Granada, the Morisco communities at the time were by and large still fluent in Arabic. ${ }^{23}$

There are also some indications which may point towards the oral usage of the material: in Lumbre de fe, as in the books by Juan Andrés and García, the vocative expressions ('you, my Moorish neighbor'; 'So now tell me, you Moor') 24 suggest that they were used to actually preach and recite the parts in Arabic. However, it would be difficult to determine if they were in fact performed in real life, and how they may have functioned when read out loud. ${ }^{25}$ Perhaps the transcriptions could have been a helpful resource for those who already knew the text by heart, as a sort of 'cheat sheet', and were most probably not to be performed by missionaries without any prior knowledge of Arabic. It is more than plausible that many Muslims of Aragon still memorized portions of the Qurān, even if they did not employ Arabic as a spoken language, as is common even today among Muslims in non-Arabic-speaking contexts. ${ }^{26}$ Preoccupation

23 It is interesting to consider the conversions that took place in 1521 in the territory of Valencia, which were encouraged and brought on by the revolts of the Germanías (Guilds), as well as Figuerola's possible involvement in this context of outspoken pressure against the Muslim communities. For more on this topic, see: Isabelle Poutrin, Convertir les musulmans. Espagne, 1491-1609, (Paris: PUF, 2012), pp. 77-111.

'Tú, próximo mío de moro'; 'Pues dime agora tu moro'; Martín de Figuerola, Lumbre de fe, fols. 33r, 187r, 189 r.

25 Martín García's original sermons were actually translated from Castilian or Aragonese vernacular into Latin, and in the printing process other features were most probably amended or adapted. In fact, even though it contains numeric references to the quotations, translations and some Arabic words, the fragments are not represented in Arabic (neither in Arabic script or Latin) as they are in Juan Andrés and Figuerola.

26 Based on the mistakes that Juan Andrés makes when he is copying fragments of the Qurān in the Confusión, we can see, as argued by Larson, that he was most likely writing the text down from memory. Everette Larson, 'A Study of the Confusión de la secta mahomática [sic] of Juan Andrés' (PhD Diss., Washington DC, Catholic University of America, 1981). 
with the proper pronunciation of qurānic Arabic, without interferences from vernacular Arabic or romance dialects, was a relevant issue, as some treatises of tajwìd ('to make better, to embellish', used to refer to the rules of recitation of the Qur'ān) have been preserved from this very same area of Aragon. ${ }^{27}$ In tajwid, the emphasis was placed on how to pronounce Arabic correctly, on the contrary to the lahn al-'ämma ('errors of language made by common people'). According to one of the treatises preserved in the Aragonese communities, incorrect pronunciation of the Arabic phonemes would ruin the sacred words, would diminish their value, and would even jeopardize the reward for prayer. ${ }^{28}$

In his prologue to the Arte, Pedro de Alcalá explains that categories of words remain the same in the different languages, so if Pedro is a proper name it remains the same in Arabic too. He comments as well that despite the tendency of Arabic to be 'deficient' in verbal structure, this does not imply that it lacks other elements in the rest of the parts of the sentence, which most probably entails an effort to equate the Arabic language to Latin or Castilian as a fully legitimate vehicle to transmit Christian doctrine. ${ }^{29}$ There is at the same time an acknowledgment of translation as an operation that entails restrictions, but which can essentially serve as a neutral signifier without carrying any other essential characteristics. When providing questions to ask during the confession, he specifies that 'every language has its own way of speaking', and that not accepting this means 'to confuse more than to interpret'. In such cases, his strategy is to proceed literally or to find a different way to express the same concept: 'many of the questions are thus given literally, rendered word for word in the Arabic because the language could withstand it, and in other cases it is not so because the language could not withstand it, but it is just the same

27 Morisco manuscripts that included these treatises are: Junta 98/3 (olim) M-CCHS RES RESC/98.3, and Junta 3 (olim) M-CCHS RES RESC/3. Reinhold Kontzi, Aljamiado Texte. Ausgabe mit einer Einleitung und Glossar (Wiesbaden: Steiner, 1974), vol. 2, pp. 348-677; reviewed by Federico Corriente, 'Pronunciación del árabe', in Memoria de los Moriscos, escritos y relatos de una diáspora cultural, (coord.) Alfredo Mateos Paramio (Madrid: SECC, 2010), pp. 134-37.

28 M-CCHS RES RESC/3, pp. 446, 450-51.

29 'Y esto porque las mesmas difiniciones y declaraciones que ay en una lengua quanto a la comunicación de los términos en su manera, essas mesas son en todas las otras, mirando a la comunicación de los términos della. Ca por la mesma razón que este nonbre Pedro es nombre propio en la lengua latina, por esta mesma lo es en la araviga. Pero porque algunos no piensen que ansí como la lengua araviga es defetuosa de tiempos y modos en la materia del verbo, assí lo sea en defeto de todas las partes de la oración'; Alcalá, Arte para ligeramente saber, 'Prólogo'. 
sentence in other terms. ${ }^{30}$ These divergences between Alcalá and García's respective discourses can be understood in connection with the aforementioned problem of how to construct a convert's new faith.

So coming back to García, Juan Andrés and Figuerola, whose involvement in the evangelization of Granada began after 1500, they most probably crossed paths with Pedro de Alcalá and Hernando de Talavera, and likely consulted their material. Martín de Figuerola in fact used Pedro de Alcalá as his reference when copying Arabic letters and vowels. ${ }^{31}$ But other than providing the reader with the Arabic alphabet, there is not much in the way of linguistic study to be found in the works of these three men, since they do not include any other reflection on the grammatical or morphological components of Arabic, and do not provide any method for acquiring it, not even a glossary. Minor exceptions would be, for example, when Juan Andrés includes the Castilian counterpart to some of the Islamic words, as in alhage/romiage (pilgrimage). ${ }^{32}$ Elsewhere, he also makes a comment about a broken plural: 'the chapters of the Koran are called suar and one is called sura in Arabic'.33 But this is about the extent of the group's interest in Arabic per se.

While the fact of translating the Qurān and quoting from it (which is what García, Juan Andrés and Figuerola are doing in their books) obviously entails a range of technical difficulties, there is no clear statement by the authors acknowledging this fact. On the contrary, the texts portray the Qurān as a very approachable text (a commonplace that we could call a 'fallacy of easiness'). Is this a part of their polemical language? Here, too, there is a contrast with how Alcalá problematizes the action of translating.

30 'Deve mirar qualquier persona que leyere el presente interrogatorio y doctrina para los confessores que cada una de las lenguas tiene su manera de hablar y con aquella se deve el hombre cuerdo conformar quanto buenamente pudiere porque de otra manera más sería enfuscar que interpretar lo que onbre quisiese dezir. Es por esso en el presente interrogatorio muchas de las preguntas van así al pie de la letra sacadas punte por punte en el aravia porque lo sufrió la lengua, y otras no así porque no lo sufrió la lengua, mas solamente la mesma sentencia aunque por otros términos'; Alcalá, Arte para ligeramente saber, fol. DIII. 'Estos son los caracteres de sus letras pero tienen sus vocales que ellos dizen xuclas'; Lumbre de fe, fol. 4. In Pedro de Alcalá it reads as follows: 'Es otrosí de notar que los aravigos no tienen letras vocales como los latinos. Mas tienen en lugar dellas ciertas señales que ellos dizen xaclas'; Alcalá, Arte para ligeramente saber, fol. c, iv.

32 Other terms: Beytilleh alharam 'casa de Dios vedada', 98 [fol. $9 \mathrm{r}$ ]; çufehe 'gente necia', 102 [fol. 1ov].

33 'Los capítulos del alcoran se llaman suar y uno se llama sura en arávigo'; Juan Andrés, Confusión, p. 118. 
However, when the Martín García group translates the Qurān, as we will show further on, the authors manifest a clear awareness of the importance of another textual apparatus employed in conjunction with the sacred text, namely the tafsir. This, along with various other Islamic sources, indirectly serves to reveal the difficulty of the task. If Alcalá's comments could be understood as a sort of language ideology of Arabic and Spanish as vehicles for the transmission of doctrine, in García's Sermones, Figuerola's Lumbre de fe and Juan Andrés' Confusión we could perceive a use of the Arabic language as an authoritative rhetorical token. Even if there are signs of the texts being intended for oral performance, their effectiveness as such is probably scant, given the authors' carelessness in transcription. It would seem, then, that the texts under analysis here are far less interested in Arabic gramatiquerías than in mastering authoritative sources from Islam that could prove the latter wrong, and in arguing that even on the basis of the Qur'ān and the Qur'ān only, the one and true faith is Christianity. ${ }^{34}$

\section{'Trahet vuestro Alcorán que yo traheré el mío’: Arabic and the Qurān as Authority}

Martín de Figuerola undertook the campaigns to preach to the Moors in Aragon at the request of the bishop of Barcelona, none other than Don Martín

34 It is interesting to note that polemical materials such as these ended up being subject to censorship by the Inquisition. In fact, decades later, in 1583-84, Quiroga's index explicitly prohibited disputes and controversies between Catholics and heretics, and confutations of the Qurān in Romance; Ricardo García Cárcel and Doris Moreno Martínez, Inquisición. Historia Crítica (Madrid:Temas de Hoy, 2000), p. 323. There was also the risk of these same materials being used by Muslims as sources of doctrinal information about Islam, as Ignacio de las Casas comments in his Memorial to Cristóbal de los Cobos. Las Casas likewise criticizes some of the books of this type produced in Spain as being doctrinally inconsistent: 'Aunque an salido varios cathecismos o contra alcoranes, son en lenguas que ni éstos saben ni ven y los que para los de España an salido en la nuestra, an sido tales que, méritamente, an sido prohibidos, así porque guiándose los autores dellos por solas relaciones y por lo que hallan en otros libros atribuyen a la secta lo que no admite o niegan lo que admite, como por lo principal que se a esperimentado que, no siendo los argumentos tales que valgan a convencerlos bastamente, lo que dellos los v[e]ían, se mofavan de todo y, citando costumbres y lugares del Alcorán, los compravan (más para enterarse en sus ceremonias y costumbres, que las hallaban allí juntas, ya que no les permitían tenerlas de otra manera) que para convencerse'; Youssef El Alaoui, 'El jesuita Ignacio de las Casas y la defensa de la lengua árabe. Memorial al padre Cristóbal de los Cobos, provincial de Castilla (1607)', AREAS, 30 (2011): pp. 11-28, esp. pp. 16-17. 
García. ${ }^{35}$ Though at the time of this campaign the Muslim community had not yet been forced to convert, Martín de Figuerola exhorted them to do so. To achieve this goal, he managed to outstep the bounds of his actual assignment at the See of Zaragoza - which called for four sermons a year to be delivered to the Muslims, as instituted by the Catholic Monarchs - and went to the actual mosques to preach and debate against Islam, to which the second part of the book attests. In Lumbre de fe contra el Alcorán, the book he composed during the $15^{20}$ but never published, he narrated his own day-to-day encounters with the Muslim population of Aragon in a first-person account of this particular preaching campaign (1517-18). Despite the emphasis he places on his preaching activities and engagement in polemics against Islam, very often he seems keener on expulsion, or forced rather than voluntary conversion. ${ }^{36}$ For example, on one occasion, the son of the alfaqui of one of the mosques where he goes to preach says that he would rather go to Africa than have to put up with Figuerola every Friday. In response, Figuerola writes that 'I told him to go ahead and do it', and later on, 'The sooner our land is cleaned up the better.' ${ }^{37}$

In one of the aforementioned preaching campaigns, specifically that of 20 September 1517, he challenged the alfaqui as follows: 'To find out if all these questions are true, bring your Koran next Friday, and I will bring mine. Then right here we will see if what I am saying is true. ${ }^{38}$ Earlier that same month and year (11 September 1517) he had entered one of the mosques and brought with him a copy of the Qurann. While he was waiting for the service to finish, he looked through the book to find passages which would serve for a disputation and - based on his account - by doing so he troubled the alfaqui so much that the latter made no less than forty mistakes in his speech: 'And I took the Koran and began to leaf through it to find the texts with my questions; and the alfaqui,, who saw that I had the book, became so agitated that he made forty-three mis-

35 'El presente autor predicando en la yglessia mayor de Saragoza en presencia de los moros que eran unos sermones de la fe los quales el rey Católico Fernando de Aragón le mandó que tomara el cargo por la antigüedad del Mq Xd Martín García, obispo de Barcelona'; Martín de Figuerola, Lumbre de fe, fol. 103r.

36 For more on Martín de Figuerola's attitude on this topic, see Mercedes García-Arenal, 'The Double Polemic of Martín de Figuerola's Lumbre de fe contra el Alcorán (1519)' (University of Pennsylvania Press, forthcoming).

'Le dixe que mucho en hora buena que lo hiciese'; 'Que primero quede nuestra tierra limpia'; RAH, ms. Gayangos 1922/36, fol. 243 r.

$38 \quad$ '... para conocer si son verdaderas estas questiones, traet vuestro alcoran para el viernes que viene, que yo traheré el mío, y aquí comprobaremos si es verdad lo que yo digo'; Guillén Robles, Leyendas de José, p. lxxiii. 
takes in the prayer he was delivering, according to what I was told by a Moor who was there at the mosque. ${ }^{39}$

In the challenge that Figuerola posed to measure the alfaqui's copy against his own copy, we can see how the book, as an object, becomes a metonymic stand-in for the whole of Islamic doctrine, and ultimately confrontation comes down to one object wielded against another: 'look here at the book, bring yours here; these are the texts ... everybody have a look, take it and read it. In the end, he [the alfaqui] did not want to read them: ${ }^{40}$ Indeed, the physical presence of the book illustrated in the foregoing examples mimics fairly well the actual apparatus and construction of the polemical work undertaken by García, Juan Andrés and Figuerola. In their writings, the Qurān is recurrently presented in the text by showing and exhibiting passages from it on the written page, in a very similar way to how the physical book is brought to the mosque. There seems to be a parallel in the use of Arabic language which likewise fulfills the role of an authoritative, almost symbolic element. Though carefully included, it is nevertheless not necessarily used as a true communicative vehicle, nor does it function as a means of actually transferring doctrine, as the Arabic language does in Alcalá. In Lumbre de fe, fol.12v, [see fig. 7.1] we can see a clear example of how the passages from the Qurān are included in the treatise:

Libro tercero Capitulo segundo alea cient y bint y dos y dize así: Cala acbita mine jarmien bacdum libiedin aduum ${ }^{41}$

39 'E yo tomé el alcorán, y empecé de cartear para buscar los textos que mis questiones tenían; y el alfaqui que vió que yo estaba con el libro, tomó tanta alteración que erró la oración que azía en cuarenta y tres veces, segun yo fui informado de hun moro que allí estaua en la mesquita'; Guillén Robles, Leyendas de José, p. lxxiv.

'Mirad aqui el libro, venga aqui el vuestro; aqui los textos ... mirenlo todos, tomad y leed. En fin que él no quiso leerlos'; Guillén Robles, Leyendas de José, p. lxxvi.

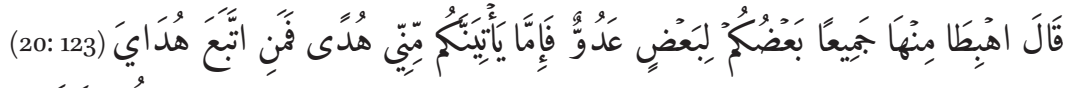

He said: ‘Get ye down, both of you, all together, from the Garden, with enmity one to another: but if, as is sure, there comes to you Guidance from Me, whosoever follows My Guidance, will not lose his way, nor fall into misery'; (trans.) Yusuf Ali. Early Modern Christian polemicists were eager to quote Muslim authorities on the characters of the Old and New Testaments; the gloss to verse 2:198 in Egidio da Viterbo's Qur'ān, a Latin translation closely related to the ones presented here, informs that Adam and Eve met again on the Mount 'Arafāt, having been expelled from Paradise. This exegesis can be found in works of such authorities as al-Zamakhsharī and Ibn 'Ațiya. See Thomas Burman, Reading the Qur'ān in Latin Christendom, 1140-156o (Philadelphia: University of Pennsylvania Press, 2007), p. 160 and p. 273, n. 31, 32. 


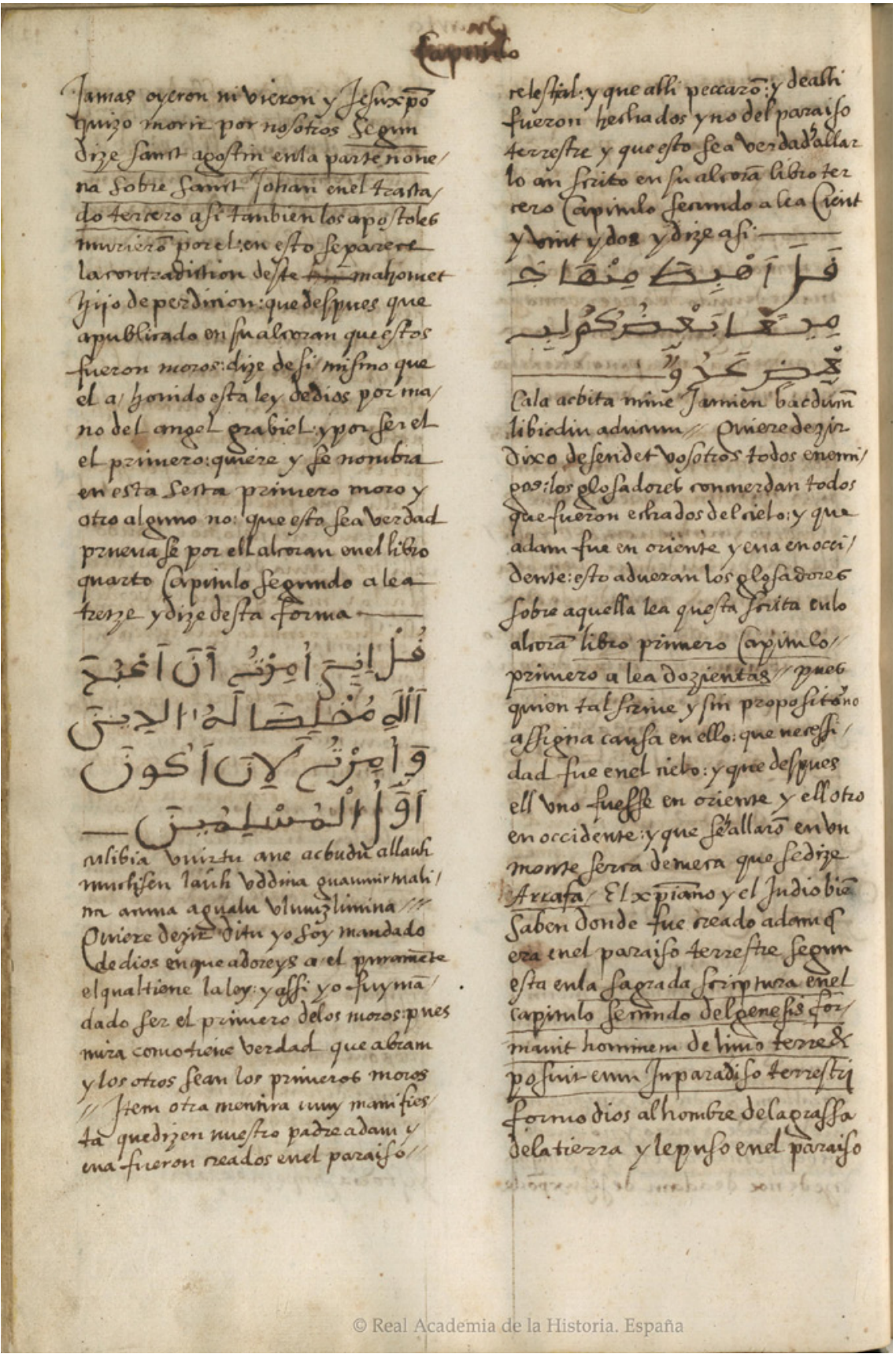

FIGURE 7.1 Real Academia de la Historia, ms. Gayangos 1922/36: Joan Martín de Figuerola, Lumbre de fe contra la secta mahometana y el alcorán (1521); fol. 12v. 


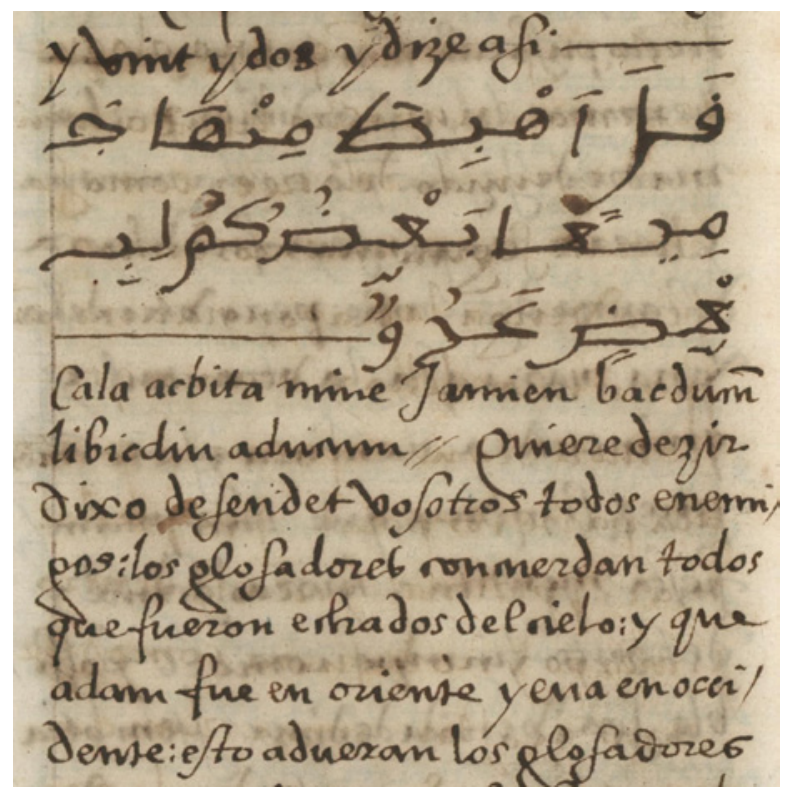

FIGURE 7.2

Real Academia de la Historia, ms. Gayangos 1922/36:Joan Martín de Figuerola, Lumbre de fe contra la secta mahometana y el alcorán (1521); f. $12 v$, detail.

Quiere dezir dixo defendet vosotros todos enemigos. Los glosadores concuerdan todos que fueron echados del cielo, y que Adam fue en Oriente y Eva en Occidente.

The inclusion of such quotations follows this order in a more or less consistent way: (1) Referencing the passage following the four-part Maghrebian division, which was wide spread in the Peninsula in the time. ${ }^{42}(2)$ Including the text of the Qurān in Arabic and in Latin characters. (3) Translating and commenting on the fragment, and in doing so usually keeping the translation of the Qurān separate from its exegesis, sometimes referred to as 'the gloss'. Also somewhat typical is the poor quality of the writing, in this case even cutting the word جميع into two [see Fig. 7.2].

Martín de Figuerola's clear awareness of the central position of the book within the community is evident in his interactions with the Muslim communities of Aragon and his determined inclusion of qurānic passages in his sermons and writings. He seems to have understood that more than just the

42 See Margarita Castells Criballés, 'Alguns aspectes formals de la traducció llatina de l'Alcorà de Robert de Ketton (c. 1141-43) i la seva relació amb el text original àrab', Faventia, 29.3 (2007): pp. 79-106 and Consuelo López-Morillas, El Corán de Toledo. Edición y estudio del manuscrito 235 de la Biblioteca de Castilla-La Mancha (Gijón: Trea, 2011), pp. 39-40. 
doctrinal vehicle of the community, it is also a key source of authority. This conception most probably implies in the first place a translation of the Christian idea of the sacred text as one book that contains all the main doctrinal references. Thus, the Qurān is seen as the counterpart of the Bible, which mirrors the medieval disputes based on the equivalence between the two texts. ${ }^{43}$

Other arguments defended by Figuerola reflect further basic misconceptions about Islam. Among them, that the message of the Qurān was mainly the message of Muhammad and that it lacked continuity (style-wise) with the previous revelations. ${ }^{44} \mathrm{He}$ repeatedly attributes the word of the Qurān to Muhammad, as in the following passage: 'One of them replied, saying that whoever wrote it had lied. I replied back, saying: What you say is in the wrong, since he who wrote it, as he is a Christian, is more truthful than you, and has written more truthfully than your Mohamed, or any of your scholars, who are full of a thousand vices' [emphasis ours]; or elsewhere: 'Mohamed writes in his Koran book' 45

Despite all of his misconstructions and flaws, it seems that the inclusion and exhibition of the Arabic quotations did have an effect on the alfaqui, as Figuerola mentions in the anecdote cited above, since the leader of the community gets confused and loses track of what he is saying. Figuerola's portrayal of himself holding the Qurān in his hands and looking through it inside the

43 Norman Daniel, when speaking about the nature of the Quraann, mentions this old misconception of the Qurān as an equivalent of the Bible: 'The Qurān has no parallel outside Islam. Christians have sometimes seen it as equivalent to the Bible. They have not always realized that the Qurān describes itself (and previous revelations also, though not word for word) as copied from a heavenly prototype, so that it is really unlike anything known to Christianity. Still less have they understood that it is believed to be the uncreated Word of God. This doctrine, which was arrived at comparatively late in the development of the consensus of Islamic opinion, was yet generally accepted two centuries before the period that concerns us. The Qurān in Islam is very nearly what Christ is in Christianity: the Word of God, the whole expression of revelation'; Norman Daniel, Islam and the West: The Making of an Image (Edinburgh: Edinburgh University Press, 1960), p. 53.

Norman Daniel, on 'The alien qualities of the Qurān', asserts: 'Much medieval argument depended on showing that the Qurān was incongruous with the other revelations with which it associated itself. This was more a matter of logical inconsistency. It was held to be incompatible with Scripture in its inherent qualities, and not only with Scripture, but with philosophy and natural reason also. Its strangeness and unfamiliarity in certain ways were genuinely shocking to the Latin reader; in Western tradition it stood out as a freak, both in content and in form'. Daniel, Islam and the West, p. 77.

'Respondió y dixo uno, que mentía quien lo auía scrito. Respondí y dixe: Vos hablais muy mal, porque quien lo á scrito, siendo xpiano, tiene mayor verda que no vos, y á scrito más verdadero que vuestro mahomet, ni todos vuestros doctores, que están llenos de mil maldades'; 'Mahoma Scribe en su Alcoran libro'; Martín de Figuerola, Lumbre de fe, fol. 18r. 
mosque thus has a metaphoric value. The scene parallels his use of transcribed fragments of the Qur'ann in the construction of the written polemical discourse of Lumbre de fe, the flustered alfaqui mirroring Figuerola's desire to unmask the institution of Islam.

Concerning the mechanics of how the Arabic text and Qurann are appropriated in the book at the formal level, the inaccuracy of the Arabic script and the poor quality of the transcription are rather striking, especially when compared with other materials such as the already mentioned Arte by Pedro de Alcalá, and later catechetical material such as Martín de Ayala's (1504-66) Doctrina Christiana (1566), ${ }^{46}$ where there is a genuine effort to provide graphic signs for all Arabic phonemes, including the sophisticated use of accents. ${ }^{47}$

However, the qurānic fragments inserted in Figuerola's text actually bear a formal resemblance to some of the late production of Islamic materials written in Spain in Latin characters (the late sixteenth and early seventeenth centuries) ${ }^{48}$ This proximity is also mirrored in the use of tafsir (commentaries to the Qur'ann) and other authoritative sources in the translations that are provided, which Martín de Figuerola explicitly mentions: 'Use the Koran, lead them by the hand using their own scholars who glossed the Koran'. ${ }^{49}$ Almost all the excerpts are glossed and explained according to Muslim tafsir authorities, at times cited by name: 'Their own scholars, Azamaxeri [al-Zamakhsharī], Beratia [Ibn 'Ațīya], Buzamarim [Ibn Abī Zamanīn], Almacodi [al-Mas'ūdī (?)] say the same thing, that is what the Arabic says. ${ }^{50}$ This reliance on Islamic source material extended beyond tafsir to include a variety of other books that

46 Doctrina Christiana en lengua Aráuiga y Castellana (Compuesta por mandado del illustríssimo y Reverendíssimo Señor don Martín de Ayala Arçobispo de Valencia: para la instructión de los nuevamente conuertidos deste Reyno) (Valencia: J. Mey, 1566).

47 Federico Corriente in his edition of Alcalá's vocabulary has commented that despite limitation in his Arabic and linguistic notions, and the printing problems that his work implied, the contribution he makes is still remarkable. Federico Corriente, El léxico árabe andalusí según Pedro de Alcalá (Madrid: Universidad Complutense, 1988), pp. ii-iii.

48 As in the Mohammad de Vera treatise: 'Y quando acabarás el alguadó, dirás: axahadu an laylahila Alla guahedahu, laxarica lahu gua aztaefirulL ${ }^{a}$ aladi lailahila hugua gua tubu ylLahi gua axahadu ana Mohanmad dun raçurulL ${ }^{a}$, quiere dezir, Hago testigo que no ay dios sino el verdadero Dios, él solo, sin aparçero; i pido perdón a Dios, aquel que no ay otro dios sino él; y arripiéntome a él; y hago testigo que Mohanmad fue su siervo y su mensajero; Raquel Suárez García, El compendio islámico de Mohanmad de Vera. Un tratado morisco tardío (Oviedo: Universidad de Oviedo), p. 177 (forthcoming). We want to thank Raquel Suárez for sharing her book with us before its publication.

'Usa el Alcorán, tómales tú la mano con los doctores suyos que an glosado el Alcorán'; Martín de Figuerola, Lumbre de fe, fol. 253.

'Doctores suyos Azamaxeri, Beratia, Buzamarim, Almacodi dizen lo mesmo, el arabigo es que dize'; Martín de Figuerola, Lumbre de fe, fol. 26v. 
circulated widely at the time, such as the Risāla of Ibn Abì Zayd al-Qayrawānī (d. 386/996), ${ }^{51}$ a treatise on Mālikī law that was very common among Mudéjares and Moriscos: 'I would have put more, but I was lacking several Arabic books, and especially one called the Ricella. ${ }^{2}$ Other common sources that circulated widely among the Muslims in Spain in the Modern period were the Kitāb al-Shifā̉ by the Qāḍī 'Tyād. Figuerola claims he also has a copy of this book, and says: 'Azifaçear, a book with a great deal of authority among the Moors because of all the praise it says of Mohamed, which book was composed by one of their scholars called Alcadiajar. ${ }^{3}$ Thus, Figuerola engages in a sort of mimicry of the Islamic sources in circulation in the communities he is targeting. However, this appropriation, whose clear intention is to make a show of the author's familiarity with the material, leaves him in a position of proximity as well.

Far from approaching Islam from the vantage of Christian tradition proper, the attack on the Muslim faith actually inserts itself within the formats and textual tradition of the Islamic community through a relationship of marked dependency that undermines the faith almost from within. Even the exhortation to compare the different Qurâns that Figuerola mentions in the anecdote quoted before when he challenges the alfaquí to bring his copy of the Qur'ān to the mosque, may be something more than an aggressive summons to a polemical contest. It may in fact have been objectively necessary for a discussion to decide what a Qurān contains, since most of the material which circulated in Aragon in the sixteenth century consisted of excerpts, fragments, selections of quotes or parts of the entire unabridged version. ${ }^{54}$ We also know of fragments and abridged versions of the Qurān which circulated among Muslims, and which focused on utterly different aspects of the holy text. And it is here where the distance between the two types of qurannic quotes is most noticeable. Consuelo López-Morillas states in her study of the Qur'ān and the Moriscos

51 Mercedes García-Arenal, 'Algunos manuscritos de Figh andalusíes y norteafricanos pertenecientes a la Real Biblioteca de El Escorial', Al-Qanțara, 1 (1980): pp. 9-26, esp. p. 20.

52 'Pusiera más, sino que he tenido falta de algunos libros arábigos y en especial uno que se dice la Ricella'; Martín de Figuerola, Lumbre de fe, fol. 239.

'Azifaçear, un libro de mucha autoridad entre los moros por tratar de las muchas alabanzas que dice de Mahomet, el qual libro fue compuesto por un doctor dellos que se dice Alcadiajar'; Martín de Figuerola, Lumbre de fe, fol. 134r.

54 On this subject see Consuelo López-Morillas, 'The Genealogy of the Spanish Qurān',Journal of Islamic Studies, 17 (2006): pp. 255-94; and Nuria Martínez de Castilla Muñoz, 'Qur'anic Manuscripts from Late Muslim Spain: The Collection of Almonacid de la Sierra', Journal of Qur'ānic Studies, (2014): pp. 89-138. Also, Jacqueline Fournel-Guérin in 'Le livre et la civilisation écrite dans la communauté morisque aragonaise (1540-1620)', Mélanges de la Casa de Velázquez, 15 (1979): pp. 241-59, mentions that Miguel Luengo, a new convert to Christianity, compared his Qurān with another's copy arguing about which one was better and more true: 'disputando qual era mejor y más verdadero'. 
that the thirteen examples of the abridged and abbreviated Quranns used by the Mudéjares and Moriscos 'consisted of the chapters and verses most recited in daily prayer'.55 Moreover, López-Morillas underscores that the qurānic passages translated by Juan Andrés correspond 'only rarely (13 times) to those found in the "standard' abridgement of the Qur'ān so common among the Moriscos.56 The Christian polemicists were only using the Muslim commentaries in reference to the core fragments and concepts which they saw as especially convincing in proving the inferiority of Islam, not the 'Quraan' that the Mudejares used on a day-to-day basis and were familiar with.

Therefore, in spite of the formal and rhetorical similarities with circulating Morisco material for Muslim use, we can perceive the texts written by the authors from Martín García's circle as being impregnated with a strictly Christian way of reading and analyzing the Qurān, albeit with some innovations. Figuerola, who introduces himself as a maestro en sacra teología (master in sacred theology), apart from quoting the Qurān and Islamic sources, quotes abundantly from the Bible, providing the text in Latin normally followed by its translation into Spanish, in a very similar way as he does with the Qur'ān.57 Other Christian religious sources also find their place in his writing, such as Dante, Duns Scotus, St Augustine and Llull's Blanquerna. He abundantly quotes the Apocalypse, Leviticus and the Epistles of Peter and Paul, as well as St Augustine. An argumentative enterprise of this nature required not only a working knowledge of Arabic sources - mainly the Qurān and tafsìr on top of other Islamic doctrinal texts as we have said - and expertise in qurānic language, but also some familiarity with both the Christian polemical tradition and Islamic doctrinal texts, plus firsthand knowledge of religious practices.

While Martín de Figuerola and Martín García coincide in their use of Christian sources and tradition, Juan Andrés notably does not, rarely drawing on such materials. Thus, Juan Andrés normally proceeds by providing information from Islamic scripture and then contesting it, and sometimes his response is even highlighted in the printed version by the graphic sign of a little hand in the margin, manecilla, on the whole following a very methodical, rational way of arguing. Most of the polemical tone is much more contained and far less apparent than in Martín de Figuerola. Although in the prologue he does use as a much more rhetorical and conventional device - terms such as 'perverse, evil, fake' this language is relatively uncommon in the rest of the text. ${ }^{58}$ Even in

55 López-Morillas, 'The Genealogy of the Spanish Qur'ān', p. 262.

56 López-Morillas, 'The Genealogy of the Spanish Qurān', p. 277.

57 As in Lumbre de fe, fol. 53r, where he quotes Jeremiah, 16: 'Ecce ego mittam piscatores multos dixit Dominus et piscabuntur eos. Dice el señor, yo embiaré pescadores muchos y los pescarán'.

$5^{8}$ Juan Andrés, Confusión, p. 91: 'Acordé de componer la presente obra por recolegir en ella 
his style of arguing, with its softer polemic tone and more argumentative structure, the use of Islamic sources is still not neutral or comfortable, but rather creates a complicated tension around authority, since these sources are needed on the one hand in order to prove that they themselves are wrong, while on the other they are sometimes also used to reinforce the Christian message itself.

Juan Andrés, for example, would dedicate the eleventh chapter of his Confusión o confutación de la secta Mahomética y del Alcorán to 'How the Christian faith is proven to be good and holy and true and God-given by the Qur'ān itself and the Sunna of Muhammad and how the Qur'ān bears witness to the existence of Jesus Christ our Lord. ${ }^{59}$ This argument is preceded by several chapters containing an extensive argument questioning the veracity of Islam and the Qurān. In a similar fashion, Martín García, in his sermon Contra infideles et hereticos, in quo probatur messiam uenisse per statuam, danielis 2, would argue that through the Qurān one could learn about the existence of idolatry in the time of Muhammad, taking this testimony almost as a historical source: 'So the whole world was full of idols and not just the Jewish world, but also the Hagarenes, as Muhammad bears witness regarding his relatives.' ${ }^{6}$

Another concern that shows through clearly in Juan Andrés, but which is far less prominent in Martín de Figuerola, has to do with the inimitability and perfection of the qurānic revelation as a proof of its authenticity. Figuerola in fact seems appalled by the Qurān and finds it to be formally incongruous. He sees in its versified form a clear sign of its inauthenticity, engaging again with classical Christian polemical debate, commenting that 'it looks like at the end of the world God turned into a songster.'61 Juan Andrés, on the other hand,

algunas de las fabulosas fictiones, trufas, engaños, ninerías, bestialidades, mentiras y contradictiones de passo en passo qu'el perverso y malvado Mahoma, para decebir los simples pueblos, ha dexado sembradas por los libros de su secta y principalmente en el Alcorán'.

59 'Capítulo onzeno: tracta como la fe cristiana esta provada por buena y sancta y verdadera y dada por dios por el mesmo alcoran y en la suna de Mahoma como faze testigo Elcorán de Jesu Christo nuestro señor'; Juan Andrés, Confusión, pp. 210-17.

6o 'Et sic totus mundus plenus erat idolis non solum iudei, sed agareni, ut testatur Mahoma de parentibus suis' Montoza Coca, 'Edición, traducción', pp. 66-67. García will also use the authority of the Qurān to reinforce the argument in his third sermon: 'Et dicitur in plerisque azoris, id est, capitulis, quod hic Yce filius Marie fuit messias, quem in arabico nominat Maceh aut Maçiha. Hoc etiam habetur in alcarano, sic dixerunt angeli Marie: Deus nunciat tibi uerbum suum. Nomen cuius est Ihesus Christus filius Marie magnus in hoc seculo. Loquetur hominibus suauiter adhuc puerulus, et erit primus sanctorum'.

61 'Parece que dios en la fin del mundo se hiciera copleador'; Martín de Figuerola, Lumbre de fe, fol. gv. 
while indeed presenting the text as having 'no foundation nor reason', 62 avoids any sort of attack based on the formal grounds of the Qurān. He criticizes Muslims' excessive devotion to the actual letters and formal structure of the book, depicting pious Muslims as a sort of alphabetical fanatics, a vision that is actually closer to the Muslim perception of the Qurān mentioned before as described by Norman Daniel:63 'You hold it [the Qur'ān] in such esteem that you kiss it when you take it into your hands and you swear by it: and you mistake it for God'; 64 or, more vivid still: 'Because if a Moor took out one letter or misplaced one diacritic or one accent, then he would be sent off to be stoned by the law and by the Sunna'.65

In a similar divergence from traditional Christian polemicists, who attacked Muhammad as a charismatic charlatan, Juan Andrés shies away from personal attacks on his former prophet. For example, explicitly citing the well-known Kitābal-Shifā̄ by the Qādị, cited above by Martín de Figuerola, in his Confutación Juan Andrés recounts the anecdote of Muhammad's scribe 'Abdallah Celen who was originally a Jew', that is the well-know Jewish convert to Islam 'Abd Allāh b. Salām, ${ }^{66}$ recounting that, since he 'was familiar with the law of the Jews, he realized that everything Muhammad told him to write down was fiction and falsehood'. ${ }^{67}$ Thus, he undertook a 'great experiment' to alter the endings of the verses while maintaining the rhyme scheme to see if Muhammad

62 'En la ley de Mahoma no ay fundamento ni razón para que pueda ser verdadera'; Juan Andrés, Confusión.

63 See note 43 .

64 'que te parece de tal escriptura: la qual tienes en tanta reuerencia que la beseys quando lo tomeys en las manos y jureys por el: y lo tomeis en lugar de dios'; Juan Andrés, Confusión, pp. $128-29$.

65 'Pues dime agora tu moro y mira que ley tienen los moros en el Alcoran y como lo guarden. Ca si un moro quitasse una letra o mudase una tilde o un acento luego le mandarían ser apedreado por ley y por çuna'; Juan Andrés, Confusión, p. 122.

66 "Abd Allāh b. Salām in Muslim tradition has become the typical representative of that group of Jewish scribes which honored the truth, admitting that Muhammad was the Prophet predicted in the Torah, and protecting him from the intrigues of their co-religionists'. Joseph Horovitz, “Abd Allāh b. Salām', Encyclopaedia of Islam, 2nd ed. (Brill Online, 2015).

67 Some relevant bibliography about the presence of this book among the Moriscos; Javier Albarrán Iruela, Veneración y polémica. Muhammad en la obra del Qāḍ̄ Tyāẹ (Madrid: La Ergástula, 2015); Luis Fernando Bernabé Pons, 'El Qāḍī 'Iyāẹ en la literatura aljamiadomorisca', Sharq Al-Andalus, 14-15 (1997-98): pp. 201-18; Louis Cardaillac, Moriscos y cristianos. Un enfrentamiento polémico (Madrid: Fondo de Cultura Económica, 1979), pp. 156-59; and Gerard A. Wiegers, A learned Muslim Acquaintance of Erpenius and Golius. Ahmad b. Kasim Al-Andalusi and Arabic Studies in the Netherlands (Leiden: Rijksuniversiteit, 1988). See also Chapter 8 in this volume by Gerard A. Wiegers. 
noticed, and indeed, in seven years he did not. ${ }^{68}$ The use of this anecdote by a convert from Islam is interesting on many levels. For our purposes, we might highlight that, at the very least, the fact of Muhammad's deceit is not emphasized; another way of reading between the lines of the text is that Muhammad was merely reciting what had been revealed to him but, unfortunately, the text that Muslims revere today has been adulterated (in this case by none other than a Jew). And this is precisely the argument that Muslim polemists so often used against the Christians and Jews, known as tahriff, that the revelation was true and the messengers righteous, but its transmission fatally flawed.

As to the issue of whether or not the alfaquís, and indeed the Muslim community, were ignorant of their own faith, which, as we shall see in the following section, was one of Figuerola's key allegations, it is also interesting to note that Juan Andrés would recurrently address his interlocutor as 'you who read the Qur'ān every day' and similar formulas. Despite the polemic tone (and also a hint of sarcasm) there is a key difference with regard to Martín de Figuerola's ignorant alfaquís and Moors, as Juan Andrés imagines a dialogist who is, at the very least, well read, even though he implies that despite all of this reading the interlocutor has understood nothing.

Thus, subtle differences manifest in Juan Andrés and Figuerola's approaches to the discourse, and in the way they present themselves and the content of their own books. Similar fragments of the Qur'ān are included in both Lumbre defe and Confusión, at the same time as Islamic texts and the Arabic language are put on display as a powerful authoritative device, all the while being denigrated and stripped of their authority in a broader sense. Clearly in both Juan Andrés and Figuerola there is an underlying ideology in which it is not enough

68 'En tanto que Mahoma tuvo un escrivano que se llamava Abdalla Celen, el qual era judío de primero, y este fue escribano de Mahoma diez años. Y comoquier que havía estado judío y era entendido en la ley de los judíos, vino a conoscer que todo lo que mandava Mahoma a él d'escrivir era cosa ficta y fingida y no de Dios dada. Y con todo quiso fazer y fizo grande experiencia, la qual fue que quando Mahoma le mandava escribir los versos siempre trastocava la fin del verso, a saber es, mudando las palabras de la fin del verso. Y no mudava el rima ni la consonancia porque avéys de saber que el Alcorán va todo por rima y por consonante, así como metros. De manera que quando Mahoma mandava al escribano que escriviesse y posiesse en la fin del verso: alla hazizum haquini ponía el dicho escribano: allha cemihum halim; que quiere decir que quando Mahoma le fazía escribir que dios era glorioso y sabidor: ponía el escribano: "Dios es oydor y juez" y si Mahoma le mandava escribir que Dios era poderoso y muy alto, ponía el escribano: "Dios es perdonador piadoso" y desta manera estuvo este escribano siete años trastocando la fin de los versos y mudándolos. Y nunca en todo el tiempo hubo Mahoma sentimiento dello y así vino a conoscer este escribano que si el Alcorán fuesse de Dios no passara tanto tiempo que Mahoma no oviesse algún aviso de Dios y de su amigo el ángel. Todo esto pruevo por el libro que se llama Assifa y por el libro de Acear'; Juan Andrés, Confusión, pp. 121-22. 
to offer Christian doctrine; rather, the tenets and traditions of Islam must be engaged with, only to be turned against the religion itself, proving the veracity of the Christian faith, while inadvertently endorsing certain aspects of Islam. This process of arguing makes us wonder if this unintended proximity could also have affected the preacher's own system of belief. In other words, it raises the question, whose answer is beyond the scope of this paper, of how one can pick apart another's faith, entering into debate and dialogue with them, without accidentally casting doubt on one's own beliefs.

\section{'Siendo christiano, tiene mayor verda que no vos': Converted Alfaquís and Christian Source Material}

Through his accounts of the morerías of Aragon, Martín de Figuerola makes the interesting claim that normally the Muslims from Aragon do not engage in polemics: 'they do not dispute with anybody about their Law' ${ }^{69}$ Figuerola attributes this attitude to teachings of the Qurān, but also appears to interpret it as a sort of passivity, a compliance that he sees as a symptom of ignorant believers who blindly follow the alfaqui. ${ }^{70}$ In fact, it is this figure who becomes the target of the disputation, and consequently is severely distorted in Figuerola's depiction, ${ }^{71}$ represented not just as the person who holds religious knowledge, but also the person responsible for feeding his community lies and steering it away from salvation. ${ }^{72} \mathrm{~A}$ similar emphasis on the importance of dispensing

69 'Que no disputan con nadie de su ley'; 'Según yo tengo experiencia de algunas disputas con ellos que no quieren admitir ningún doctor de los nuestros y algunos de los suyos tienen esta astucia que si alguna autoridad trahays de sus doctores que no los satisfaze dizen que el tal doctor no le tienen por auténtico'. Martín de Figuerola, Lumbre de fe, fol. $32 \mathrm{v}$ and $4 \mathrm{r}$.

$70 \quad$ 'Donde está la ceguera destos próximos mios de moros que sus alfaquis les dan a entender tales cosas sin dar razón ni causa'; Martín de Figuerola, Lumbre de fe, fol. 23 r.

The term alfaqui corresponds to the Romance version of the Arabic faqīh, which means an expert in Islamic jurisprudence. However, in the context of the early sixteenth century in Spain, it seems that the term is used in a much wider sense, meaning someone who is knowledgeable in Islam, the leader of the community, and often the one who performs the functions of the Imām in the mosque, as is described in Martín de Figuerola's text. It seems reasonable that the pressure to convert which was on the rise in Aragon, and had already been mandated in other areas of the peninsula, added a new layer to the situation of the Muslims in Spain, and most probably affected concepts such as hegemony and authority within these Muslim communities, where traditional authority roles gradually became more blurry and less visible. About the role of alfaquís in Late Medieval Spain, see: Kathryn A. Miller, Guardians of Islam: Religious Authority and Muslim Communities of Late Medieval Spain (New York: Columbia University Press, 2008).

'Pero marauíllome de tantos hombres que aquí están, que uso de razón tienen, que no 
with this figure may also be observed in the Instructions for the Valencian Moriscos based on the Juntas of 1561, where agreements were reached on forcing all the alfaquís and dogmatists to leave the kingdom, stating that they 'are not to be there because they will ruin every instruction that could be given'. ${ }^{73}$

And yet, at the same time as Figuerola targets this figure as a repository of knowledge, interestingly enough his criticism takes on an unexpected twist by accusing the alfaquis themselves of being ignorant. He is actually quite categorical on this point: most of them are flat-out ignorant, do not have a sound command of Arabic, as with the Muslims in the aljamas (Muslim neighborhoods), and their only merit is to have learned the Qur'ān by heart. ${ }^{74}$

However, there is still a further twist in such statements as the following: 'but I am surprised that all these men who are here, who have the use of reason, would not see what they have, and they have to content themselves with your simple reason [that of the alfaqui], while they all know that what I say was written by the alfaquís converted to Christianity'. Indeed, his attempt to legitimize his own arguments through reliance on a new Christian / former Muslim authority is a double rhetorical effort: on the one hand, it seeks to open up a channel for polemics from within, while at the same time resolving the preachers' own anxiety over using Islamic sources, filtered through a new Christian faith: 'He who wrote it, as he is a Christian, is more truthful than you'. ${ }^{75}$

During his preaching campaigns in Aragon, Martín de Figuerola was actually accompanied by the new Christian Juan Gabriel, former alfaqui from Teruel Alí Alayazar, ${ }^{76}$ who did not pen any treatises of his own, but was in fact commissioned by Italian Cardinal Egidio da Viterbo (1469-1532) to translate and transcribe the Qur'ān. ${ }^{77}$ In February 1517, they attended prayers at the mosque on the day of the celebration of the prophet Muhammad's birth, about

quieran ver lo que tienen, y que de vuestra simple razón se ayan de contentar, conociendo todos ellos, que esto que yo digo lo an scrito alfaquis hechos cristianos'; Guillén Robles, Leyendas de José, fol. lxxv.

'Que en todo caso los alfaquies y dogmatistas salgan fuera del Reyno, y que no estén allí porque destruyrán toda la instruction que se hiziere'; Mercedes García-Arenal, Los moriscos (Granada: Universidad de Granada, 1993), p. 110.

'No sabeys lo que haveys de guardar y seguir, cosa es confusa tener y seguir una escriptura que nadie la puede entender'; Martín de Figuerola, Lumbre de fe, fol. 17iv.

'Quien lo á scrito, siendo xpiano, tiene mayor verda que no vos'; Martín de Figuerola, Lumbre de fe, fol. 18 r.

76 García-Arenal and Starczewska, 'The Law of Abraham', pp. 409-59, esp. p. 412.

77 Starczewska, 'Latin Translation of the Qurān (1518/1621) commissioned by Egidio da Viterbo. Critical Edition and Introductory Study' (PhD Diss., Universitat Autònoma de Barcelona, 2012). See also Starczewska, 'Juan Gabriel', in Christian-Muslim Relations: A Bibliographical History. Vol. 6. Western Europe (1500-160o), (ed.) David Thomas et al. (Leiden: Brill, 2014), pp. 415-19. 
which festivity Juan Gabriel had provided some information. Figuerola waited with him at the mosque while the prayers were taking place, looking for an opportunity to initiate a religious dispute: 'I was well informed of the story and of how he was born [that is the Prophet Muhammad] by one called master Juan Gabriel, who was the alfaqui of Teruel and now, by the grace of God, is a Christian.' ${ }^{78}$ Also when quoting Juan Andrés, Martín de Figuerola would refer to him as an expert, since he was a former alfaqui, and a new trustworthy Christian source. ${ }^{79}$ Juan Gabriel and Juan Andrés are thus not only the informants and mediators, but also authorities.

The use of the intermediation of converts or Muslims is definitely not new, but the insistence, the naming and locating of the precise characters involved, is significant. Since Martín de Figuerola's Islamic and Arabic knowledge was transferred mainly from former Muslims as he himself declares, and specifically former alfaquís, his repeated emphasis on the ignorance of the alfaqui certainly creates some fissures in his argumentation. ${ }^{80}$ One could also wonder if the constant accusation of the lack of knowledge among the Muslim communities at the time in Spain, a commonplace that has persisted down to the present day in the literature about the Moriscos, ${ }^{81}$ is perhaps connected precisely to this brand of polemic literature and its topoi, and that the time has come to question it or at least examine it from a more critical perspective.

\section{A Rational Conversion: Oratory, Logic and Grace}

Juan Andrés, in the prologue to his book, narrates his own conversion, describing it through semantic elements that could likewise be understood as a way of proposing an ideology of conversion where the latter is reached through

78 'Siendo bien informado de la historia y de cómo nació por uno que se decía maestre Johan Gabriel, alfaqui que era de teruel y ahora por la gracia de Dios, xpno'; Guillén Robles, Leyendas de José, p. lxvi.

79 'Mossen Johan Andres antiguo alfaqui de Xativa y que por ser persona experta'; Martín de Figuerola, Lumbre de fe, fol. 3 or.

80 'porque el alfaquí, después de haver yo predicado, juntaua toda la gente en la mesquita, según yo fui informado, que les dezía: Todo lo que a dicho mossen figuerola no a dicho verdad ni le creais. Y ellos, como simples ignorantes que no saben lleer ni entender ell alcorán, ni saben algarabía, que todos son algimiados, dauan fé al dicho alfaquí; y yo siendo certificado, vue de tenelles otra arte, y les dixe en una predica todo lo que el alfaquí hazía; y por tanto yo determinaua de hir cada viernes que ellos tienen aljoma, y allí en la mesquita, delante de todos, con el alcorán, les mostraría ser verdad todo lo que yo les predicaua; y assi empezé de hazer las infrascriptas disputas, en su mesquita, á las quales mucha gente, así letrados como no letrados, concurrían'; Guillén Robles, Leyendas de José, pp. lviii-lix.

See Chapter 11 by Mercedes García-Arenal in this volume. 
rational channels. In Juan Andrés' account, he entered the Cathedral of Valencia and upon hearing the renowned fray Juan Marqués preaching, 'The radiant rays of the divine light ... stirred and illuminated the darkness of [his] understanding, opening up the eyes of [his] soul' (emphasis ours). ${ }^{82}$ Afterwards, Andrés says that he then knew that only through the law of Christ was salvation possible, and then decided to ask to be baptized. Even though, as is to be expected, the narration bears the habitual symbols and narrative conventions of conversion (light, brightness, sudden change), ${ }^{83}$ the semantic framing of the process indicates a much more rational event than in conventional narrations of conversion, as Andrés understands, knows, and decides what to do. This choice of wording depicts the whole process as being much more premeditated and thought-based. Understanding the acquisition of a new faith as a reason-based channel would very much justify the nature of a polemic work like Andrés' Confutación, Martín García's Sermones and Martín de Figuerola's Lumbre de fe, where discursive preaching and argumentation are the legitimate means of arriving at the truth. Also, while 'light' could of course be understood as a supernatural component, it could also refer to the light of understanding and reason, as this was also a common trope at the time. ${ }^{84}$

Whether Juan Andrés' Islamic training reflected or not the common training of an Iberian faqi $h$ in this period is difficult to analyze based on a book like this one, which evidently passed through the significant filters of its sponsors and printers. We might note however that the strategy of reasoning and arguing to win over converts to Christianity, which is consistent throughout the book, also shares some common traits with the Dominican order and their production of material that exhaustively tracked their opponents' own doctrines. ${ }^{85}$ Three woodcuts are included after the introduction to the Confusión:

82 'Los resplandecientes rayos de la divina luz ... removieron y esclarecieron las tinieblas de mi entendimiento y luego se me abrieron los ojos de la anima'.

83 Ryan Szpiech, 'Preaching Paul to the Moriscos in the Confusión o confutación de la secta Mahomética y del Alcorán (1515) by Juan Andrés', La Corónica, 41, no. 1 (Fall 2012): pp. 31743; and Szpiech, Conversion and Narrative: Reading and Religious Authority in Medieval Polemic (Philadelphia: University of Pennsylvania Press, 2013).

84 In the prologue to his translation of the Disticha Catonis, Martín García writes: 'Así como lumbre es escuredat / [a] quien tiene privada potential visiva, / quien tiene ofuscada su intellentia / el dezir fundado fallia seguedat'; Martín García Puyazuelo, La ética de Catón, (ed.) J.F. Sánchez López (Zaragoza: Instituto de Estudios Aragoneses, 2009), p. 5.

85 It seems that practices used by the Dominicans in the thirteenth century were centered on the Jews more than on the Muslims, and that their argumentative approach developed into an aggressive tone and exhaustive debates, especially in the territory of Aragon. Examples of these practices are the works by Ramón Martí (d. 1285): De Seta Machometi (composed before 1257), the Explanatio symboli apostolarum (written in 1257) and Pugio 
the Pantocrator; a representation of the Order of Preachers, including their shield and motto, and another of the Virgin Mary standing on a column holding the baby Jesus, with the Apostle St James at her right and the Monarchs at her left. We know that Juan Andrés was not a member of the Order of Preachers and neither were Martín de Figuerola or Martín García. However, Juan Andrés seems to link himself to another ecclesiastical figure, that of Juan Marqués, a Dominican from Valencia and confessor of the king Fernando the Catholic. ${ }^{86}$ In his own account, Juan Andrés describes this friar as the preacher who brought about his conversion. Marqués was apparently gifted with outstanding rhetorical skills, which were described as if his words had almost a physical effect on the audience, words like 'great stones', as in the anecdote that Francisco Diago (ca. 1560-1615) relates in his Historia de la provincia de Aragón de la orden de predicadores (1600), which involved king Fernando as well. ${ }^{87}$ Due to his skills, Marqués was chosen first as the king's own confessor, and then as the monarchs' official preacher in 1476.88

fidei (composed in 1278), as well as those by Ramón de Penyafort (d. 1275). See John V. Tolan, Sarracens: Islam in the Medieval European Imagination (New York: Columbia University Press, 2002), p. 235.

86 Some other biographical references about Juan Marqués may be found in fray Baltasar Sorió, De viris illustribvs Provinciae Aragoniae Divinis Predicatorum, (ed.) J.M. de Garganta Fábrega (Valencia: Institució Alfons el Magnànim, 1950). He also shows up in Jacques Quétif and Jacques Echard, op, Scriptores Ordinis Praedicatorum (Paris 1717-21; Turin, 1961), and Celedonio Fuentes, Escritores dominicos del Reino de Valencia (Valencia: Ángeles Pitarch, 1930).

87 Francisco Diago, Anales del Reyno de Valencia (Valencia: Pedro Patricio Mey, 1613), and Diago, Historia de la provincia de Aragón ([Barcelona]: Sebastián de Cornellas, 1599). Diago tells how the king heard Marqués preaching, and in a later encounter on the street that same day approached him and made a public display of his admiration by placing his hand on the friar's head and exclaiming in front of the members of his court: 'What great stones Father has thrown at us today!' 'Auiale oydo predicar en Caragoça día de san Esteuan tan a gusto suyo que yendo el mismo dia por la ciudad acompañado de todos los de su corte no lo pudo dissimular. Que viendo todos ellos ponían los ojos en la puerta de una casa pregunto luego lo que mirauan. Y respondiéndole que al maestro fray Ian Marques que se auía puesto allí hasta que su Magestad passasse, lo hizo desde luego salir y poniéndole la mano encima de la cabeça dixo a los grandes. Que buenas pedradas nos ha tirado oy el padre! [emphasis ours]. The gesture of the hand over his head could be read as the sign of the beginning of a connection that was to develop into subsequent responsibilities in the church, first as the king's own confessor, and then as the monarchs' official preacher in 1476 .

88 Here Diago includes a letter from the king bestowing upon him the title of preacher and enjoining him personally to take on the role: 'Juan Marqués religioso tan letrado que llego a ser predicador. Que ambos los dos titulos le dio en el sobrescrito de una carta que le escrivió desde Tudela a cinco de Abril de mil y quatrozientos y setenta y seys, 
Even though no direct connection has yet been established between Marqués' involvement in preaching activities and the conversion of the Muslim population, ${ }^{89}$ the fact that Andrés mentions him by name as the one responsible for his conversion led Ximeno, in the aforementioned work of $1700,{ }^{90}$ to blend together Diago and Andrés' testimonies, so as to portray Marqués as an eloquent and effective preacher who converted the famous alfaqui from Xàtiva. He writes, 'In his preaching his eloquence was so sublime, and his power of persuasion so powerful and effective, as is made clear by the marvelous conversion of that famous Moor, alfaquí of Xàtiva, who at his baptism wanted to be named Juan Andrés.91

It is interesting to note that Marqués and García, the two most hierarchical Church figures in the network around Juan Andrés and Figuerola, shared some of the same positions, since in 1486, just ten years after Marqués was appointed confessor to the king, none other than Martín García was to be found holding the very same position as Marqués, chosen to be the confessor to the queen and official preacher of the monarchs. A similar narration of García's elo-

mandándole que le fuesse a predicar el Iueves santo y el Viernes santo tambien la qual sacada del Archivo desde conuento y traduzida de Lemosin en Castellano es la que se sigue. Maestro Marques. Nosotros escriuimos al tesorero del conve[ $n]$ to que os recado con que vengays. Ma[n]damos os seays aqui en todo caso Miercoles primer viniente para que nos podays predicar el Iueues y Viernes Santos. Y no aya falta. Dada en Tudela a cinco de Abril, mil y quatrozientos y setenta y seys. Rex Ferdinandus'.

89 A comparison between Marqués' sermons and those of Martín García could perhaps be illuminating in order to track the evolution of the rhetorical apparatus and focus of interest in relation to these topics, but unfortunately Marqués' writings have not been preserved. An inventory of his library was made by order of Queen Isabel, who after his death in 1499 seized it and had it brought back to the court, arguing that she felt a great devotion to him: 'E perque tenim molta devocio en les obres fetes per aquell, volem en tot cas tenirlos' The list of books made on this occasion contains titles such as the following, which could be understood as sermons named after the day they were meant to be recited: sermo de Cena Domini, sermo de Sanct Julia, sermo de Sant Arcis, Sanct Senet, Sancti Sebastiani, Sancte Anne, Dominice IV Adventus, Dominice III Quaresme, Dominice X Adventus. Some are unfinished ('Sancti Jacobi; non est acabt'), and the list also includes the works of the Dominican Aquinas and Augustine's Confessions. José Toledo Girau, 'La librería de un obispo valenciano incautada por la reina doña Isabel la Católica', Anales del Centro de Cultura Valenciana, 44 (1960): pp. 78-88.

90 Vicente Ximeno, Escritores del Reyno de Valencia, chronologicamente ordenados desde el año MccXXXVIII de la christiana conquista de la misma ciudad, hasta el de MDCCXLVII (Valencia: Joseph Estevan Dolz, 1747).

91 'En la predicación era su elocuencia tan sublime, y su persuasiva tan poderosa, y eficaz, como lo manifiesta la maravillosa conversión de aquel célebre Moro, Alfaquí de Xátiva, que en su Bautismo quiso llamarse Juan Andrés'. 
quence is offered by his biographer Hebrera, and may also be observed first hand in his production of sermons written in Latin. Moreover, Marqués was succeeded in his position as bishop of Patti in 1500 by Miguel de Figuerola, the uncle and protector of Martín de Figuerola. These biographical facts tracking a series of connections and projects in common, all linked in one way or another to the Catholic Monarchs and the emergence of a new way of approaching an increasingly forced conversion, point to an intriguing network of churchmen. Further study into this line of research could shed light on the emergence of this particular school of polemics and preaching, and the evolution and spread of its ideology of conversion.

As is probably clear to anyone working with similar topics to the ones covered in this chapter, materials that deal with the idea and praxis of conversion reveal views about how one's faith can become another's faith, what elements are shared, what elements must be erased. In the reality analyzed here - the books produced by Martín García, Juan Andrés and Figuerola - this thinking about how to convert takes on a discursive form (they are written testimonies of what could have been an oral practice) that grew out of a very specific context: Granada and then Aragon in the first decades of the sixteenth century.

Thus, in Lumbre de fe, Confusión and Sermones, dealing with another's faith and conversion comes down mostly to words, meaning that attention to language is a high priority in order to understand how such discourses are articulated and constructed. In this verbal battle pitting Christianity against Islam, words can be as physical as stones (as seen in the above-mentioned anecdote about Juan Marqués), ${ }^{92}$ and so dynamic that they can flow from one language to another in a constant exercise of translation and interpretation marked by numerous constraints. Considering the language ideology that is inevitably behind every choice made in the so-called polemic literature, we have wished to analyze some key elements that shape this language, the language of polemics, such as the use of Arabic, the insertions of qur'annic text, and the authorial voice constructed around the former and current alfaquís.

The materials examined have shown that Arabic still possessed a very powerful authoritative value at the moment when the texts were used and distributed, serving as sufficient reinforcement to religious arguments even if the language itself was not properly written or widely understood. At the same time, contrasting with more linguistically oriented texts such as those of Pedro 
de Alcalá, the lack of background knowledge, or the extreme dependence on others' intermediation, revealed a much more symbolic use of the language in the polemic text that may appear at first glance.

The vehemence and violence that typify the language of polemics has interested us less than the strong capacity of this discourse to propagate a set of long-lasting notions about Muslims that would be passed down in the history of ideas. However, at the same time, by directly engaging with and disseminating knowledge about Islamic beliefs and practice, they created ambiguities about what position to confer to them, which is perhaps more evident in Juan Andrés than in Martín García or Figuerola. Beyond their energetic and straightforward tone, a common element underlying the language of polemics employed by all three authors is, as we have said, a use of the qur'ānic text and the Arabic language itself as important symbolic and authoritative elements. While they of course built their authority through other strategies as well, such as inserting themselves within genealogies of Christian authorities, or presenting religious ideas with a hint of rationalism, of primary interest to us is the fact that to legitimize their arguments in the eyes of both Muslim and Christian communities, these authors focused on Islamic elements sometimes as much or more than Christian doctrine, leading to a perhaps uncomfortable proximity. 